\title{
Towards Improvement in the Teaching of Reading Comprehension in Primary Schools: The Need to Activate Pupils' Relevant Schema
}

\author{
Hanna Yusuf \\ Curriculum Section, Faculty of Education, Ahmadu Bello University, Samaru-Zaria, Nigeria \\ Email:hannayusuf@yahoo.com
}

\begin{abstract}
This paper reviews some aspects of the Reading process that are relevant in activating Pupils Schema. It also discusses how pupils' schema could be activated through pre-reading activities and background knowledge/experience. The paper concludes by recommending in a step by step sample lesson plan, the need to guide pupils to have expectation for their reading and the need to constantly engage them in meaningful conversation, that is in consonance with what is about to be read and what is being read. All these would help to make reading comprehension lessons more enjoyable and meaningful.
\end{abstract}

Index Terms —improvement, reading, comprehension, activate, relevant, schema

\section{Definitions OF READING}

According to Dearman and Alber (2005), "reading is the process of stages of developmental skills that culminate in reading mastery."(p.21). Thus, ability to communicate via the print involves the development of perceptual processes, experimental opportunities, cognitive abilities and other aspects of human endeavour, all of which operate in and contribute to the meaning of reading.

Reading involves perception and cognition. Contrary to the decoding definition of reading, are those definitions which view reading as a two dimensional act. Doherty (2002) and Smith (1971) as well as some other researchers in reading have taken this position. The definitions which fall into this category, suggest that reading involves not only visual perception of the written symbols, but also thoughtful responses of the reader. This implies that the intent of the reader and the background he has to work with in responding to what he reads permits the development of a new understanding and modification of old concepts. The implication of this definition for the teacher is the concern with word perception skills and with the ability on the part of the reader to interact with the author in diverse thoughtful ways.

\section{THE NATURE OF THE READING PROCESS}

Widdowson (1979) suggests that reading is the realization of general interpretative process which underlines all communicative activity. This process operates at the different levels of mental activity. The first level is the immediate apprehension of information and second, the discrimination of this information into patterns of conceptual significance (p.56). Extracting meaning from a text depends crucially on two things: the reader's knowledge or schemata and purpose which depend on the writer's effectiveness in giving the reader the necessary pointers to activate knowledge and absorb new knowledge from the text.

Some other linguists believe that reading is a matter of maturation rather than a process developed through systematic instruction and practice. Some see reading as primarily a visual task, its study and development lies in the use of mechanical device designed to record eye movements and to increase reading speed by expanding eye span intake of printed symbols. Others view reading as a matter of accurate pronunciation which emphasizes phonic instruction or modifies the orthography to ensure more specific letter - sound relationship. A few views reading as a complex process integrating all aspects of human behaviour and demanding varied and continued instructional guidance to read accurately and efficiently, to appraise what is read, and to relate what is read in a significant way to other areas of life.

On the whole, one would agree that reading is a key to wealth of experience that links people in a way that is not limited by distance or time. Reading provides experience through which the individual expands academic and intellectual horizons, identifies, extends and deals with personal interest and attitudes that affect the task of reading (Smith, 1971, p. 84). To enhance comprehension, therefore, various strategies are set in motion: the three basic ones being:

- skimming to get the gist of a text;

- scanning to locate specific information; and

- inferring and predicting meaning through the cohesive and coherent devices used in the text.

In the school setting, reading should be seen as not only enabling the students to interact with text to negotiate 
meaning, but also to transfer that ability to other subject areas. To any set of learners, reading should be linked with the extension of actual experience.

A lot of work abounds on the various techniques of teaching reading comprehension using contextual clues, the dictionary, synonymy, structural and morphological clues, use of cohesive ties etc (Ayuk, 1989; Williams, 1983; Obah, 1989 etc). Teaching students to comprehend texts in the target language (i.e English, which is the medium of instruction in all the other subjects) without making them conscious of the relevance and applicability of such in the other subject areas may not lead to full realization of the aim of reading.

An important axiom is that texts relevant to student's discipline must be used to teach language points and these tally with the schema theory of background knowledge as an aid to information processing in fostering understanding and comprehension (Smith, 1975, Widdowson, 1979 and Oyetunde 2009).

From the above discussion on the reading process, it is clear that reading is interactive and multi-level orthographic phonological, lexical, syntactic and semantic as well as discourse activities. Also important is the ease with which the pre-existing schemata are activated by the incoming 'data' from the text. It is the opinion of this study that a reader's existing schematic knowledge is as important as what is contained in the text by way of 'content'. It is also clear that reader's purpose in approaching a text is of vital importance. The popular notion probably held by many Nigerian teachers is that reading is the ability to pronounce words. That is, it is assumed that children can read once they can translate writing into speech sounds. The fact, however, is that it is possible to pronounce all the words in a passage beautifully and still be unable to make sense of it. Reading is far more than the ability to pronounce words on a page. It involves the recognition and interpretation of symbols. Reading also involves using both the information provided in the text by the author as well as the sources of information outside the text. (Yusuf 2005, 2009)

The reviews above have thrown up a perspective of the fact that the information needed in order to comprehend a text does not come from the text alone. What is already known about the topic of the text, as well as the familiarity with the words and sentence structure used, play an equally important role in comprehension. This means that during reading, there is interaction between what the text says and what the reader already knows. The option that reading is a process of interaction between the author and the reader is considered appropriate. In other words, during the reading process, the reader is actively trying to make sense of the written or printed text by integrating previous relevant experiences with the text information.

It is now recognised that the reader draws a number of sources of information, both from text itself and from the individual reader. The text information includes the print itself, often referred to in the literature as grapho-phonic cues (Goodman, 1969) or perceptual information (Yorkey, 1970). The information the reader contributes to the reading task includes the intuitive knowledge of the language being read (syntactic information), knowledge of the vocabulary used in the text, as well as background of information or "prior knowledge" related to the topic of the text. Both of these are part of the semantic information drawn upon during the reading process.

Pre-reading activities are of crucial importance in activating pupil's relevant schema (Ayuk, 1989; Williams, 1983; Obah, 1989; and Oyetunde, 2009). Some of the activities that may be relevant in helping teachers to achieve this include:

a) asking pupils questions on the topic of the text itself in order to brainstorm as to what they expect the text to contain, which may be continued, refuted or moderated later by the text content;

b) getting pupils to draw or label a diagram related to the topic or text;

c) asking pupils to attempt the comprehension questions before reading the text;

d) Teacher drawing up his own questions based on the text as pre-questions on the subject matter of the text;

e) giving pupils a task centred on a problem, the solution of which can be checked in the text:

The above activities serve as a guide and arouse interest on the:

i. purpose of the text

ii. information contained in it; and

iii. value of such information to the pupil.

The pre-reading activities are thus mental set devices that pupils can find to be of immediate use in the disciplines, since reading involves a network of information processing. The author is of the opinion that if reading is approached from this perspective, it becomes a skill that is functionally and pragrammatically oriented towards achieving the desired literacy level in the academic as well as the society at large. If reading is properly taught, a lot of misreading, both in specialist area and in matters of general concern such as government policy, and newspaper articles that can lead to national chaos or upheaval will be avoided. Pupils will be able to read, understand and contribute positively in the class and the society, and thereby, widen their horizon conceptually in all aspects of life.

\section{The NeED TO ACTIVATE PUPILS' RELEVANT SCHEMA}

A modern psycholinguistic perspective on reading is based on insights derived from contemporary linguistics and psychology. From this perspective, reading is viewed as a complex information processing skill. The reader is seen as an active, planning, decision making individual, who co-ordinates a number of skills strategies to facilitate comprehension. Goodman (1967) attacked previous views of reading involving exact detailed, sequential perception and identification of letters, words, spelling patterns and large language units. He sees reading as a "psycholinguistic 
guessing game" involving interaction between thought and language (p.27).

Smith (1971) and Folarin (1997) elaborated on this position by emphasizing two important contributions from psycholinguistic research to demonstrate that the efficient reader does not proceed in a rigid word-by-word fashion, decoding information from print to speech to aural comprehension. First, there is a severe limit to the amount of information that we are able to receive, process, and remember. Second, research has demonstrated that reading is only incidentally visual (Kolers, 1969 cited in Yusuf, 2005, p.70). More information is contributed by the reader than by the print on the page. Readers understand what they read because they are able to take the stimulus beyond its graphic representation and assign its membership in an appropriate group of concepts already stored in their memories.

Interactive approaches which emerged in the 1980s emphasized that meaning is not fully present in a text waiting to be decoded. Rather, meaning is created through the interaction of the text and reader. Information processing based on linguistic input from the text is called bottom-up or text based processing. In the bottom-top conception of reading, the written text contains the meaning, information or message which a reader must obtain. It views reading more or less as a process in which the reader merely goes to the written text and more or less effortlessly takes away the meaning, information or message conveyed by the text. All that a reading teacher ought to do then, is to teach how the linguistic constituents of the written text convey meaning. Armed with this understanding, the reader merely goes to them and obtains their message or information. It is this bottom conception of reading that has wrongly given the impression that reading is passive and that all that a reader does is merely to obtain designated information from the written text.

The other view which also regards reading as an interactive process is the top-bottom. Exponents of this view see reading as dynamic and pragmatic. It is a process in which the reader brings into the written text as much experience or information as possible. According to this view, the totality of information which a reader obtains from the written text is determined not just by the text content.

The foregoing has revealed clearly that the reader needs a relevant schema to be able to comprehend a given text. Experiential background appears to be the most powerful factor that brings forth the schema. Below is a lesson guide on how to activate pupils' relevant schema using a prose passage titled "Farming in Nigeria" selected from Macmillan English textbook for primary five.

\section{SAMPLE LESSON GUIDE}

Step 1: Teacher guides pupils to have expectations for their reading by highlighting the following

(a) You are going to read a passage about 'Farming'

(b) You are going to read about what farming is

(c) What farmers need to do to harvest good crops and the modern methods/equipment that can help farmers increase their yield.

Teacher guides pupils to set a purpose for their reading by asking them the following questions

* What is farming?

* What tools do farmers need to work on their farms?

* Have you ever visited a farm? How does it look?

* What are the things you see on a farm?

* Have you ever seen a farmer working on his farm?

* What do farmers do during planting season?

* How do farmers harvest their crops?

* What are the equipment farmers use to harvest their crops?

* In what ways can a tractor help farmers?

As children answer the above questions, they are unconsciously relating what they already know (background knowledge) to what they are going to read in the passage.

Step 2: Teacher engages children in a discussion in line with their answers to the guided questions above, for instance, how do farmers harvest their crops? There could be several responses ranging from farmers using local tools to farmers using sophisticated equipment.

Step 3: Children are allowed to read silently for some few minutes. Teacher goes round the class as children read to correct bad reading habit such as pointing to words with fingers, vocalization, vigorous head movement etc.

Step 4: Children are requested to pick out the difficult or new words from the passage. Teacher writes such words on the board. Teacher guides students to understand the meaning of the difficult or new words in the context in which such words appear in the passage. The teacher does this by referring the children to the paragraph where such words appear and asking the children to use the sentences surrounding such words to guess their meaning. The teacher should ensure that he/she is not quick at giving the meaning of difficult or new words right away. The teacher should encourage the children to use the context of the passage to determine the meaning of such words. Teacher can do this by asking the children to say what they think the word means in the context of the sentence it appeared.

Step 5: Teacher goes further to guide the children in understanding the meaning of the difficult words by using them in meaningful sentences. He then guides the children to use such words in their own sentences. Teacher should try as much as possible to ensure that children make meaningful sentences.

Step 6: Teacher should lead children in activities that could enhance language proficiency such as purposeful 
conversation through guided questions. Such questions should be framed in line with the three levels of comprehension, viz, literal factual, inferential and critical levels. Below are some examples

* What do farmers do during planting season?

* Does the use of tractor make it easier for farmers to harvest their crops?

Why do you think so?

* What other modern farming equipment can assist farmers to get their jobs done with ease and speed?

* If you were a farmer what would you like to do to ensure good harvest of your crops?

* In what ways can Government assist farmers to improve their harvest?

Teacher should provide expected answers to the questions in his lesson. Teacher should ensure that children are taught how to answer comprehension questions. One way of ensuring this is to make sure children justify their answers in the passage by reading aloud specific portions of the passage to support their answers.

Sometimes children can be asked to retell orally the passage. Children should be encouraged to retell the passage using possible simple diction. Regular exercise of this nature will enhance children's language development.

EVALUATION: Teacher should provide questions for the children to answer in their exercise books. Some of the questions answered orally could also be included in the written exercise. Teacher should go round the class to mark. This will help the teacher to know whether the lesson was successful. It will also help the teacher to know the areas to emphasize in the concluding part of the lesson.

SUMMARY: The teacher concludes the lesson by highlighting some of the important information about the passage. The teacher also answers the evaluation questions with the children. He writes the answers to these questions on the chalkboard as the chalkboard summary.

HOMEWORK: Teacher gives children homework. Teacher can provide two or three additional questions on the passage for children to answer at home.

\section{CONCLUSION/RECOMMENDATIONS}

Teachers can apply the same format written in the above sample lesson for other similar prose comprehension passages in pupils' English textbooks. This will definitely help to make reading comprehension lessons more enjoyable and meaningful.

Teachers should be creative in devising strategies to draw upon pupils' experiential background. One way of doing this is by providing prior knowledge questions directly related to the new knowledge to be gained from the passage (see example in step I of the sample lesson).

Teachers should realise that the use of prior knowledge questions would assist pupils to match new in-coming textual information in order to derive meaning. There is therefore the need for teachers to stimulate pupils existing knowledge and make them relate it to their background knowledge of the text. Each reading comprehension passage introduced to students should reflect the fact that the purpose of reading comprehension is to make sense of print.

Teachers therefore have the responsibility of ensuring that students make good sense of the printed text by activating their relevant schema through prior knowledge questions that will stimulate them to make use of their background knowledge or experiences.

\section{REFERENCES}

[1] Ayuk, M.E. (1989). A reappraisal of some criteria for development of foreign language reading skills programs at the tertiary level in Cameroon. A paper presented at the NESA Conference, University of Ibadan.

[2] Dearman, C.C., Alber, S. (2005). The changing face of education. Teachers cope with challenges through collaboration and reflective study. Newark; USA.

[3] Doherty, R.W. (2002). Transformed Pedagogy organisation, and student achievement. New Orleans, LA; USA.

[4] Folarin, A.O. (1997). "The place of reading in the students" effects to learn English as a second language. In E. Abe, B. Lawal, E. Onukaogu, T. Jegede (eds) literacy and reading in Nigeria Vol 7.

[5] Goodman, K.S. (1967). Reading; A psycholinguistic guessing game. Journal of the Reading Specialist Vol. 6; 126-135.

[6] Goodman, K.S. (1969). Is linguistic approach an improvement in reading instruction? In N.B. Smith, (ed): Current issues in reading. Newark; Delaware. International Reading Association.

[7] Kolers (1969). Cited in Yusuf, H.O. (2005). A comparative study of the effectiveness of Language development and vocabulary methods in teaching Reading Comprehension. Unpublished Ph.D Dissertation. University of Abuja.

[8] Kuhu, M. (2005). Helping students become accurate, expressive readers. Fluency Instruction for small groups. In the Reading Teacher Journal of International Reading Association. Newark, USA Vol 58, n. 4 December/January 2005 pp 338-347.

[9] Obah, T.Y (1989). Improving Standard of teaching reading in Nigeria Schools - A Re-conceptualisation. A paper presented at the XIX Annual Conference of the Nigeria English Studies Association (NESA), University of Ibadan.

[10] Oyetunde, T.O. (2009). beginning reading scheme: Empowering teachers to help their pupils become good readers. Jos: LECAPS Publishers.

[11] Smith, F. (1971). Understanding reading: A psycholinguistic analysis of reading and learning to read. New York: Hold, Rinehart and Winston.

[12] Smith, F. (1975). Comprehension and Learning: A conceptual framework for teacher. New York: Holt, Rinehart and Washington.

[13] Widdowson, H. (1979). Explorations in Applied Linguistics. Oxford: Oxford University Press. 
[14] Williams, R. (1983). Teaching the Recognition of cohesive ties. Reading in a foreign language, I (1), 35-52.

[15] Yorkey, M. (1970). Study skills in English. London Macgraw - Hill.

[16] Yusuf, H.O. (2005). A comparative study of the effectiveness of Language development and vocabulary methods in teaching Reading Comprehension. Unpublished Ph.D Dissertation. University of Abuja.

[17] Yusuf, H.O. (2009). Strategies for improving the teaching of reading Comprehension in Primary Schools. Journal of Educational Research and Development. Vol 4(3), 63-68. Zaria: ABU Press.

Hanna Yusuf was born in Ilorin, Kwara state in 1964. She has the following qualifications: Doctor of Philosophy (PhD) in Curriculum Studies (2005), University of Abuja, Nigeria, Masters Degree in Teaching English as a second language (1996), Ahmadu Bello University, Zaria, Nigeria, Bachelor of Education Degree in Language Arts, Ahmadu Bello University, Zaria, Nigeria, Nigerian Certificate in Education (English major) (1984) A.B.U. Zaria.

She has worked in the following organizations; Universal Basic Education Commission, Abuja, Nigeria as a Research Officer, Principal Project Officer and Chief Monitoring Officer 1989-2006. She transferred her services in 2006 to Ahmadu Bello University, where she currently works in 2006 as a lecturer in the Curriculum section of the department of Education, Faculty of Education. She teaches both undergraduate and post graduate students. She is a member of the internal and external Oral Examination panel for Masters and $\mathrm{PhD}$ degrees. She has supervised and graduated a few masters' degree and $\mathrm{PhD}$ students.

Dr (Mrs.) Hanna Yusuf is a member of the Reading Association of Nigeria (RAN), International Reading Association (IRA) and Curriculum Organisation of Nigeria (CON). She has some publications to her credit among which are: (1). Yusuf, H.O. (2009) "Strategies for improving the teaching of reading comprehension in primary schools." Journal of Education Research and Development. Zaria: ABU (2). Yusuf, H.O (1997) "Effect of Direct-Reading-Thinking Activity Approach on pupils' reading comprehension" Literacy and Reading in Nigeria, vol 7. (3). Yusuf, H.O (2001) "How to make and use a big book to teach reading in the primary school", UBE digest vol. 1 No.1. 